\title{
Feeding the crusades: archaeobotany, animal husbandry and livestock alimentation on the Baltic frontier
}

Article

Accepted Version

Banerjea, R. Y., Badura, M., Brown, A., Morandi, L. F., Marcinkowski, M., Valk, H., Ismail-Meyer, K. and Pluskowski, A. (2020) Feeding the crusades: archaeobotany, animal husbandry and livestock alimentation on the Baltic frontier. Environmental Archaeology: the Journal of Human Palaeoecology, 25 (2). pp. 135-150. ISSN 1461-4103 doi: https://doi.org/10.1080/14614103.2019.1589924 Available at https://centaur.reading.ac.uk/82876/

It is advisable to refer to the publisher's version if you intend to cite from the work. See Guidance on citing.

To link to this article DOI: http://dx.doi.org/10.1080/14614103.2019.1589924

Publisher: Maney Publishing

All outputs in CentAUR are protected by Intellectual Property Rights law, including copyright law. Copyright and IPR is retained by the creators or other copyright holders. Terms and conditions for use of this material are defined in the End User Agreement. 


\section{CentAUR}

Central Archive at the University of Reading

Reading's research outputs online 
*Banerjea, R.Y ${ }^{1}$., Badura, $M^{2}$., Brown, $A^{3}$., Morandi, L. $F^{1,4}$., Marcinkowski, $M^{5}$., Valk, $H^{6}$., Ismail-Meyer,

K. ${ }^{7}$, Pluskowski, $A^{1}$.

${ }^{1}$ Department of Archaeology, University of Reading, Whiteknights, Reading, RG6 6AB, UK

${ }^{2}$ Dept. Plant Ecology, Lab. Palaeoecology and Archaeobotany, University of Gdańsk, ul. Wita Stwosza

59, 80-308 Gdańsk, Poland

${ }^{3}$ Wessex Archaeology, Portway House, Old Sarum Park, Salisbury,SP4 6EB, UK

${ }^{4}$ Institut für Naturwissenschaftliche Archäologie, University of Tübingen, Rümelinstraße 23, 72074

Tübingen, Germany

${ }^{5}$ The Archaeology and History Museum, Elbląg, Poland

${ }^{6}$ Institute of History and Archaeology, University of Tartu, Estonia

${ }^{7}$ Prähistorische und Naturwissenschaftliche Archäologie (IPNA), Spalenring 145, 4055 Basel, Switzerland

*Corresponding author email r.y.banerjea@reading.ac.uk

\section{Abstract}

Integrated micromorphology, plant macro, pollen, phytolith, and non-pollen palynomorph analyses from two $13^{\text {th }}$ century Teutonic Order castles, Karksi (Livonia), and Elbląg (Prussia), examine the livestock management and alimentation practices by the initial military colonisers during the Crusades. At Karksi, a key administrative centre in Livonia, in the area which later became the High Castle, the investigation of a midden and of the organic-rich sediment beneath allow the diachronic use of this area to be examined. Freshwater aquatic indicators are consistent with the occurrence of shallow stagnant water, as also suggested by a water-laid pond sediment identified in thin-section. Coprophilous spore taxa suggest the use of the pond as a watering hole. Plant macrofossils from the midden represent a range of habitats, mostly from wet/damp areas, as well as pastures and meadows, and also woodlands. Fragments of millet are embedded within herbivore dung in micromorphological thin-section showing the use of this grain as fodder. At Elbląg in Prussia, the initial Order headquarters, Trichuris sp. eggs may derive from animal feces as dung with parasite eggs was observed in thinsection, and a range of coprophilous taxa were extracted. The results from both sites show early colonisers use a mixed grain/leaf fodder diet for livestock, with a move to grain and grass later on. The results represent an important study of medieval castles from the period of active Crusading, and reveal the diachronicity of the range of livestock that the Teutonic Knights kept, whereabouts within the castles they were stabled, and livestock alimentation.

37 Crusades; micromorphology; plant macroremains; palynology, non-pollen palynomorphs 


\section{Introduction}

The beginning of the $13^{\text {th }}$ century A.D. sees a period of active crusading activity in the eastern Baltic region. Crusading armies unleashed a relentless holy war against the last indigenous pagan societies in Europe. The territories of these tribal groups were replaced with new Christian polities largely run by a militarised theocracy, consisting of the Teutonic Order, bishops and their cathedral chapters. They constructed castles, encouraged colonists, developed towns and introduced Christianity (Bartlett 1994; Berend 2005; Murray 2001; Pluskowski 2012; Pluskowski 2019). In this context of conquest and colonisation on the Baltic frontier, two $13^{\text {th }}$ century Teutonic Order castles (Fig. 1), Karksi in Estonia (Ger. Karkus in medieval Livonia), and Elbląg in Poland (Ger. Elbing in medieval Prussia), were subjected to detailed environmental analysis (using micromorphology, plant macroremains, pollen, phytoliths, and non-pollen palynomorphs) to examine the livestock management and alimentation practices associated with the initial military colonisation during the period of active crusading. Livestock management and alimentation practices are examined at these strategic castles in relation to their use and the impact of the arrival of Teutonic Order and initial colonising behaviours. This research examines specifically what animals were kept, where were livestock stabled, how were livestock being fed, how does the use of fodder reflect the use of the wider landscape, and how do these issues change through time. The integrated application of these techniques enables plant macroremains and microfossils to be examined in relation to the microstratigraphic formation processes that occurred within the unit that they were collected from.

Before the Crusades, in the area that later became Livonia as more native territories were conquered, the indigenous societies of the eastern Baltic had an established pastoral culture, revolving around the raising of cattle, sheep, goats, pigs and poultry (Blomkvist 2009, 444; Maltby et al. 2019; Maldre 2003). Documentary sources, particularly Henry's Chronicle of Livonia (Brundage 2003) and the anonymous Livonian Rhymed Chronicle, indicate that a complex provisioning system was essential from the earliest arrival of crusading armies in order to support the influx of crusaders, merchants, colonists and their heavy cavalry. The pastoral economy at this time of flux would have been highly volatile, with raiding accentuating the impact of environmental factors on herds (Goldschmidt 1979).

Documentary sources, particularly Peter of Dusburg's Chronicle of Prussia (Scholz and Wojtecki 1984), describe the Prussians as maintaining herds of cattle, sheep and goats in valley meadows and woodland clearings. The historical sources all emphasise the importance of horses for riding, although like oxen they could also be used for ploughing. Consumption of horse meat is clearly evident, but the majority of chroniclers noted the consumption of mare's milk (Popłoński 1862, 7). The arrival of the 
Teutonic Order in Prussia prompted new developments in animal husbandry and related alimentary culture. The most significant changes occurred in livestock husbandry; whilst the older system was dominated by pigs and cattle, the latter became the main staple meat under the new regime with pigs still forming an important part of the diet (Makowiecki et al. 2019).

So far, excavations of Teutonic Order castles have provided little in the way of detailed environmental evidence to understand the subsistence systems of the earliest colonisers (Pluskowski 2012, 296-297) and the organisation of these systems within castle sites has primarily been reconstructed from written sources (Pluskowski 2012, 151). This research, within the framework of The Ecology of Crusading project, seeks to redress this imbalance to provide a more nuanced understanding of the diachronic use of space and subsistence systems within castles and their commandaries, particularly during the initial period of colonisation. The Ecology of Crusading research project has now accumulated substantial environmental data from across the eastern Baltic to further our understanding of the impact of the Crusades (Pluskowski 2019; Pluskowski et al. 2019b).

\section{The Sites}

Archaeological deposits were sampled from two castles: Karksi Castle (Ger. Karkus) located in presentday Estonia, and Elbląg (Ger. Elbing) located in present-day northern Poland (Fig. 1)

Karksi Castle was an important administrative centre in Livonia, governed by an advocate. This official was based in the castle and had the role of managing resources and the provision of security. The site is situated above the valley of the River Halliste and on sandy clay loam glacial till surface geology. The multi-proxy investigation in Trench 1 (Fig. 2) of a midden that overlies 'anthropogenic peats' in the area directly below where the High Castle was later constructed, presented a unique opportunity to examine the waterlogged deposits to understand development and diachronic use of this area during the pre-construction and construction phases of the early castle (Banerjea and Badura 2019; Brown, 2019; Valk et al 2012). A spring ran through the site in the area of Trench 1, which became apparent during the excavation of the site (Valk et al 2012). The radiocarbon dates, modelled using the BACON Bayesian statistical program (Blaauw and Christen, 2011), suggest that these sediments were deposited rapidly between AD 1230-1280 (Valk et al 2012). During excavation, the deposits above the midden, contexts 8,9 , and 10, were described (respectively) as a dark soil with organics, red clayish loam, and a dark grey soil with wood chips. The midden material comprised numerous leather fragments, ceramics, wood chips, nut shells, abundant animal and fish bones, fragments of wooden 
vessels, wooden gaming pieces and tally sticks (Valk et al 2012). The formation processes of these stratigraphic units have been refined further using micromorphology (Banerjea and Badura 2019).

In the absence of comprehensive excavation and preservation of early occupation phases of Elbląg castle, relatively little is known about the internal layout of the Order's thirteenth-century castra in the eastern Baltic (Pluskowski 2012; Pluskowski 2019; Pluskowski et al 2019b). The castra at Elbląg was the administrative centre of the Teutonic Order until 1308 when it moved to Malbork (Ger. Marienburg), which then became its official headquarters. However, distinct spaces are specified in the Order's Rule, and written sources provide information on the variety of spaces within some of the larger convents from the $14^{\text {th }}$ century (Jóźwiak and Trupinda 2012). The excavations that were conducted in 2012 and 2013 ahead of development at Elbląg have produced the only example where the timbers have survived in situ from multiple phases of rebuilding (Fig. 3). The early castra was constructed in timber before it was rebuilt in stone (Fonferek, 2019). An exceptionally well-preserved and well-stratified sequence of organic-rich deposits that were interspersed with depositions of alluvial sediment was revealed. Geological, faunal and floristic investigations of the sediment under the castle demonstrate that the sediments which underlie the courtyard of the Museum of Archaeology and History in Elbląg document the evolution of this area from a relatively deep lake, Lake Druzno, through a shallowing water body, to a waterside zone, where the Elbląg River flowed into the Vistula Lagoon, by the time the timber castle was erected (Nitychoruk et al. 2016). Timbers at the base of this sequence produced a dendrochronology date of $c$. AD 1245, which means that the lowest deposits within this sequence represent the very earliest occupation and use of the Vorburg, or outer ward, of the early castrum.

\section{Materials and Methods}

\section{Sampling methods}

Monoliths were collected from both sites to sample all major stratigraphic units and their boundaries. At Karksi (Fig. 2), two, overlapping 0.5 m monoliths, 241 and 242, were collected from Trench 1 and were sub-sampled for micromorphology, pollen, NPPs, and phytolith analysis, but only data from 241 is relevant to this study. The upper deposits in 242 are probably $14^{\text {th }}$ century and there may have been some truncation when the first of the cobble pavements was constructed - and that included artefacts of $15^{\text {th }}$ century date, and so do not relate to the period of active crusading. Archaeobotanical samples (c. $5 \mathrm{~kg}$ ) were collected from the separate contexts of Trench 1. All samples represent waterlogged material with varying admixture of wood chips and small twigs. At Elbląg, two $0.25 \mathrm{~m}$ and two $0.1 \mathrm{~m}$ monoliths were collected from an area of the profile from Trench 2 with some particularly organic 
layers that were interspersed with deposits of alluvium (Fig. 3) and eight micromorphology thinsections were prepared from them, along with samples for pollen, NPPs and phytoliths from the key stratigraphic units. During excavation in Trench 2 nine samples $(c .2 \mathrm{~kg}$ ) for macrobotanical analysis were also collected. They represent separate contexts connected with moat and nearby useful layers in which organic material was visible. The uppermost context, 17 , dated to the second quarter of $14^{\text {th }}$ century, was composed of charred grains and charcoals and there was evidence of fire.

Faunal remains were recovered during excavations at both sites (Makowiecki et al. 2019; Maltby et al 2019; Rannamäe, Lõugas 2019), and the data are drawn upon here.

\section{Laboratory Methods}

\section{Micromorphology}

Six thin-sections, $11.5 \times 7.5 \mathrm{~cm}$, were prepared from sub-samples monolith 241, Karksi (Fig. 2), and eight from Elbląg were prepared in the thin section unit, University of Reading, UK (Fig. 3). The samples were oven-dried to remove all moisture and then impregnated with epoxy resin while under vacuum. The impregnated samples were placed in an oven to dry for 18 hours at $70^{\circ} \mathrm{C}$, then cut and mounted to onto a frosted slide. The sample was then cut, ground and polished to the standard geological thickness of $30 \mu \mathrm{m}$.

Micromorphological investigation is carried out using a Leica DMLP polarising microscope at magnifications of 40x - 630x under Plane Polarised Light (PPL), Crossed Polarised Light (XPL), and where appropriate Oblique Incident Light (OIL). Thin-section description is conducted using the identification and quantification criteria set out by Bullock et al. (1985) and Stoops (2003), with reference to Mackenzie, Adams (1994) and Mackenzie, Guilford (1980) for rock and mineral identification, and Fitzpatrick (1993) for further identification of features such as clay coatings. The identification of organic components was carried out with reference to materials at the IPNA, University of Basel, Switzerland.

\section{Plant Macroremains}

At Karksi and Elbląg, a $300 \mathrm{~cm}^{3}$ sub-sample of sediment was selected from each of waterlogged sample, following the standard procedure use in the Laboratory of Palaeoecology and Archaeobotany, University of Gdańsk, Poland. Samples from Karksi were pre-treated directly on the site. Flotation was conducted with 2.0, 0.5 and $0.2 \mathrm{~mm}$ mesh sieves. In the laboratory all fractions were checked for the presence of plant macroremains. At Elbląg, materials were soaked for 24 hours in weak solution of 
$\mathrm{KOH}$ and washed through 2.0, 0.5 and $0.2 \mathrm{~mm}$ mesh sieves. The remaining material from the sample was wet-sieved only through the coarse sieve in order to obtain large diasporas, normally underrepresented in the base sample. Charred material from context 17 was dried and analysed as a whole $\left(1500 \mathrm{~cm}^{3}\right)$ to address the preservation bias arising from the charring process, which could destroy completely disapores, such as weeds. Taxa names have been used after Mirek et. al (2002) and their ecological affiliation was established according to Matuszkiewicz (2008). The set of results presented in the tables is related to plants whose ecological affiliation was determinable.

\section{Pollen and Non Pollen Palynomorphs}

For analysis of pollen and non-pollen palynomorphs, samples $c .1 \mathrm{~cm} 3$ in volume were taken from monolith 241 (Karksi) and samples E1 to E4 (Elbląg). One Lycopodium tablet was added to enable calculation of pollen concentrations. Samples were prepared following standard laboratory techniques (Moore et al., 1991) including the use of hydrochloric acid (removal of carbonates), hydrofluoric acid (removal of silica) and acetolysis (removal of cellulose), with the caveat that this step may dissolve some types of parasite eggs (Reinhard et al. 1986), but it was necessary in order to analyse the same slides for both, pollen and non-pollen microfossils. Samples were mounted in glycerol jelly and stained with safranin. A minimum of 500 pollen of terrestrial species were counted for each level. Pollen percentages are calculated based on terrestrial plants. Fern spores, aquatics and Sphagnum are calculated as a percentage of terrestrial pollen plus the sum of the component taxa within the respective category. Identification of cereal pollen followed the criteria of Anderson (1979). Identification of indeterminable grains was recorded according to Cushing (1967). The pollen diagram was produced using Tilia version 1.7.16 program (Grimm, 2011).

The calculation for NPP concentration is based on a minimum sum of 200 (exotic markers + microfossils), in order to obtain reliable estimates (Finsinger and Tinner 2005). Identifications were made under light microscopy at 400x magnifications. Considering the anthropogenic nature of the deposit, formed over a short span of time and probably including dumping events, the use of NPP concentrations seems more appropriate than the use of accumulation rates, that appear more suitable to investigate natural sequences (Baker et al. 2013, 2016; Wood and Wilmshurst 2013; Yeloff et al. 2007).

\section{Phytoliths}

Phytoliths were extracted from each sample using the protocol developed at the Institute of Archaeology, University College London, UK (Jenkins and Rosen 2007), which, in summary uses the 
following stages: (1) removal of the coarse fraction $>0.5 \mathrm{~mm}$; (2) $1 \mathrm{~g}$ of the sieved fraction was weighed out; (3) removal of calcium carbonate using a dilution of $10 \%$ hydrochloric acid; (4) clay removal using a settling procedure and sodium hexametaphosphate (Calgon) as a dispersant; (5) samples were placed in a muffle furnace for two hours at $500{ }^{\circ} \mathrm{C}$ to remove organic matter; (6) phytoliths were separated from the remaining material using a heavy liquid calibrated to a specific gravity of $2.3 ;(7)$ approximately two milligrams of phytoliths per sample were mounted onto microscope slides, using the mounting agent Entellan ${ }^{\circledR}$.

Microscope slides were assessed using a Leica DMLP polarising microscope using 100x and 400x magnifications. Slides were initially assessed to ascertain if there were a sufficient number of single cells phytoliths present to take the slide to a full count. Those with a sufficient concentration and preservation of remains were fully analysed. Analysis consisted of counting and identifying a minimum of 250 phytolith forms. Phytoliths were further classified as deriving either from woody (dicotyledon) or non-woody.

\section{Formation processes within the microstratigraphic sequence at Karksi}

Monolith 241 (Fig.2) was collected from the lowest stratigraphic layers infilling the shallow, basin-like depression located in the area of the later High Castle; deposits from the later, $14^{\text {th }}$ century deposits are preserved in monolith 242. Modelling of radiocarbon dates from monolith 241 suggest that these deposits, which include midden material, formed rapidly between AD 1272 and 1290 (Valk et al 2012). Micromorphological analysis (Supplementary tables 1 and 2), outlined in detail in Banerjea and Badura (2019), refined the stratigraphic sequence (Fig. 2). Context 13, the 'peat deposit', comprises three separate depositional events: MU13a, MU13b, and MU13c. The lowest, MU13c, has been interpreted as pond sediment (Boyd 1995, 4-5). MU13b is a peat consisting mainly of organic components, $66 \%$, with some mineral inclusions, $34 \%$. There are no microlaminations and inclusions are unoriented, unrelated, random and unreferred, both of these features are different to MU13a above, which is also peat, but has a microlaminated bedding structure and plant fragments are strongly oriented, aligned parallel to basal boundary. These 'peat' deposits are better classified as anthropogenic peats (IsmailMeyer et al., 2018). The formation process shows similar characteristics to natural peat forming processes, but where organic materials from around the settlement have rapidly accumulated where there is a high groundwater table, which has preserved the organic matter (Ismail-Meyer et al., 2013, 331; Ismail-Meyer et al., 2018). Context 12, the 'midden', comprises two separate depositional events: MU12a, and MU12b. MU12a is a thin, 0.6-1.5 cm accumulation of leaf litter (Fig. 4a), which overlies a more substantial horizon formed from midden material, MU12b; this leaf litter is considered to 
represent a period of stabilisation. Micromorphology provided further information on the richness of the midden material with fish bones, burnt egg shell, hazelnut shells, and herbivore dung identified.

Pollen was well-preserved within context 13 , but a sizeable quantity of the cereal pollen was heavily crumpled and is identified only generally as Cerealia-type (Fig. 5). No pollen survived in samples from MU13b, with the majority of samples derived from MU13a. There is a wide range of herbaceous pollen types suggestive of damp and meadow environments in the vicinity. The immediate area around the castle appears to have been largely cleared of trees. There are clear differences between the pollen signal from the base of the sequence (MU13a-c) and the 'midden' deposits (MU12a and b). Microscopic indicators of freshwater habitats were recorded (Fig. 5), particularly in the lowest levels. Spores of Zygnemataceae (Spirogyra sp.) characterise shallow $(c .50 \mathrm{~cm}$ ) eutrophic pools, mostly stagnant (van Geel 2001). Tests of thecamoebians, occurring on both sites (Arcella and Euglypha spp.), also belong to taxa typical of damp environments, and confirm the presence of a shallow pond on the site (Charman et al. 2000), as suggested by a water-laid pond sediment identified in thin section, MU13c (Fig. 2). Furthermore, macroremains of Chara sp. (stonewort) oospores, typical aquatic green algae, characteristic of fresh water occurred in context 14 at the very base of the dammed pond. Fish scales (Villagran et al. 2017), were identified by micromorphology (Fig. 4b) within the remains of MU13a and MU13b, the anthropogenic peats formed from leaf fodder accumulations. There is a significant peak in Betula (birch) pollen at the top of the midden (Fig. 5), which corresponds to a thin leaf litter layer identified on the top of the midden, MU12b (Fig. 4a).

\section{Livestock management and alimentation at Karksi}

All levels at Karksi Castle, in particular the lowermost one (MU13c) show the occurrence of obligate fungal spores (Fig. 5) which only use herbivore dung as a growing substrate (Sporormiella, Sordaria, Arnium, Delitschia and Rhytidospora spp.) (Krug et al. 2004). This evidence proves the presence of animal feces in the vicinity of the sampled deposit, as dung spores have a relatively low dispersal and are regarded as indicators of local events (van Geel et al. 2003; Mazier et al. 2009). Coprophilous spore taxa within MU13c could indicate the use of the pond as a watering place for the livestock. Micromorphological analysis showed fragments of coprolites from small herbivores such as sheep or goat within the midden material, MU12b (Fig. 4c). These lines of evidence would suggest that herbivores, including sheep or goats were kept in this area, which was to become the High Castle, during this early colonising period. 
Several of the different proxies applied at Karksi provided evidence for the types of animal fodder used by the occupants of the site. Deposits MU13a and MU13b formed gradually, possibly as a result of material (foliage) being dumped at the edge of the pond. The pond would have served as a water source for livestock and mostly infilled with foliage that may represent the remains of leaf fodder, the lower unit representing leaf fodder that has been broken up by trampling (Banerjea, Badura 2019) (Fig. 2), with macroremains of Betula identified from sample 240 at the base of context 13 (Valk et al. 2012). MU13b comprises predominantly wood and twigs; and MU13a predominantly tree leaves. Branches and twigs were an important addition to leaf fodder in times of food scarcity such as winter (Rasmussen 1993), particularly for cattle and sheep in the Baltic where branches and twigs of trees and shrubs were collected from wooded meadows (Kukk, Kull, 1997). Arguably, on the basis of their large size observed using micromorphology, $>1 \mathrm{~cm}$ in transverse section, the wood and twig fragments within MU13b could represent uneaten fodder remains, which have been made available to the livestock, possibly as a result of clearance activities, adjacent to their water source; twigs and leaves with a diameter $<5 \mathrm{~mm}$ have been recorded within cow pats and sheep/goat dung pellets (Akeret and Jacomet 1997; Akeret and Rentzel 2001; Akeret et al., 1999; Fauve and Jacomet 1998).

Pollen evidence from context 13 (Fig. 5) suggests that grain and hay fodder was also dumped alongside the leaf fodder. There are large quantities of Poaceae (grass) and cereal pollen, particularly AvenaTriticum (oat-wheat). The poor production and dispersal rates of most cereals, excluding windpollinated Secale (rye) suggest nearby agricultural fields are unlikely to have been the direct source of the significant quantities of cereal pollen recorded from context 13. Instead the majority of cereal pollen is likely to derive from stored grain used for human consumption or as a component of animal fodder. The large quantity of Poaceae grains could derive from hay harvested from meadows/pastures as the primary component of animal fodder, but could also reflect pollen of a variety of grass species transported by wind over longer distances from vegetation growing within the vicinity of the site. Many of the ruderal and field weed pollen are likely to have been brought into the castle along with grain and hay, carried by insects attracted by rotting waste or derived from plants growing in the immediate vicinity. The dominance of both cereals and grass pollen within context 13 is therefore consistent with the micromorphological evidence of the deposit primarily as dumped fodder.

The midden deposits, MU12a and MU12b, contained further evidence for livestock alimentation at Karksi. Coprolites from small herbivores such as sheep or goats were identified in thin section within MU12b. Small fragments of millet (Panicum sp.) were identified embedded within the actual herbivore coprolites (Fig.4c). No macroremains of millet were recovered from the midden deposits, which 
suggests that processing waste was not discarded here, but that the grain was instead ingested as fodder. The other macroremains from Karksi represent a range of habitats, mostly diasporas of species from wet/damp areas, as well as ruderal places (Banerjea and Badura 2019). It is possible that the plant remains characteristic of the meadows/pastures come from places where animals were grazed. Traces of cereals (rye, barley, oat, wheat) were recovered, which could be used both as an element of human food or animal fodder. Preservation of pollen in 'midden' deposits (context 12) was more sparsely preserved, with the exception of the upper sample from the accumulation of leaf litter, MU12a (Fig. 5). There is less pollen of Poaceae and cereals and instead greater quantities of Brassicaceae (mustards), Ranunculaceae (buttercups), Caryophyllaceae (champions), meadowsweets (Filipendula) along with pollen of Rosaceae (rose family) and Apiaceae (carrot family).

\section{Formation processes within the microstratigraphic sequence at Elbląg}

Micromorphology identified four main changes in the deposition of sediment and use of the earliest outer ward (Supplementary tables 3 and 4; Banerjea 2019). The earliest deposits were first trampled by caprines, and were then followed by a period comprising several flooding events depositing alluvium. The analysis shows that context 26 at the base of the sequence is three microstratigraphic units (MU26i-26iii) comprising mixed lenses of trampled herbivore dung with low abundances of faecal spherulites, and alluvium (Fig. 3); the survival of faecal spherulites in a waterlogged sequence is unusual and may result from very localised preservation conditions that can occur in archaeological occupation deposits (Banerjea et al. 2015). These mixed lenses most probably formed as a result trampling activity by livestock while low level flooding took place, which deposited alluvial sediment that was subsequently trampled by animals and mixed with dung. MU26i-26iii are then overlain by a more substantial deposit of alluvium, MU25, which formed as a result of more substantial flooding of this area of the earliest Vorburg. This is interspersed with a trampled occupation surface containing fragments of charred wood and phytoliths (MU23b) with framboidal pyrite. These commonly occur in marine and perimarine environments and form at the oxic-anoxic interface (Kattenberg and Aalbersberg 2004; Mees, Stoops 2018), but also in freshwater environments due to bacterial degradation of organic matter (Ismail-Meyer et al., 2013) and in this context their formation is situated with a changing marine, fluvial and lacustrine system (Nitychoruk et al. 2016) The occupation surface is overlain by more alluvium, MU23a, although this is less substantial in thickness than MU25.

A floor-raising 'brush wood' (branches from small trees and shrubs) platform (MU20b and MU20c) was constructed over the alluvial flooding deposits, on which stabling deposits from large herbivores formed in situ. It is also possible that rather than being a platform, the 'brush wood' material 
represents a collapsed fence. Micromorphology shows that there is change later in this sequence in MU16a4 and 18b, which represent in situ stabling waste: elongated organic strands rather than pellets are strongly oriented and aligned parallel with the basal boundary. This dung material is more characteristic of that of larger herbivores such as cattle or horses, the upper part of which, MU16a4, is characteristic of a stabling crust (Brönnimann et al. 2017). A stabling crust forms as a result of trampled dung and organics from stabling waste becoming cemented by the input of uric acid (Brönnimann et al. 2017), and, as observed in MU164a (Fig. 4d), appears to have the micromorphological properties of dopplerite, which forms as a result of the decay of organic materials under wet conditions (Ismail-Meyer et al., 2018.).

The area is then inundated again with alluvial sediment, MU16a3, and when this has stabilised leaf litter, MU16a2, accumulated. The microstratigraphic sequence ends with a deposit of discarded material, MU16a1, which represents the abandonment of the area. This discarded material comprises brick, daub and burnt bone inclusions, as well as organic components such as leaves, charred cereals, wood, bark, and charred wood.

\section{Livestock management and alimentation at Elbląg}

Two horizons of livestock managements were identified within the sequence in Trench 2 through the outer ward of the castrum at Elbląg, both of which are characterised by the presence of herbivore dung in thin section (Figs. 3, 4e, 4f, 4g) and corresponding horizons of a range of coprophilous fungal spores and intestinal parasite eggs, Trichuris sp. as identified by extraction (Fig. 6), and possible Ascaris sp. (Fig. 3e) identified in thin-section (Pümpin et al. 2017). The earliest microstratigraphic units, MU26i-26iii, contain trampled ruminant dung from small herbivores such as sheep/goat (Brönnimann et al. 2017) with rare calcareous faecal spherulites. Intestinal parasite eggs, Trichuris sp., and coprophilous fungal spores are less abundant in the lower microstratigraphic units, which may be due to this area not being used at this point as a livestock stable, but as a yard area where livestock roamed and trampled around. The trampling of dung by animals may prevent the fungi from growing to disperse the spores (Morandi 2018). The stabling crust, MU16a4, contained the greatest abundances of coprophilous (Sporormiella-type, Sordaria-type, Sordaria cf. fimicola) and occasionally coprophilous fungal spores (Chaetomium) and intestinal parasite eggs (Trichuris sp.) (Fig. 6).

Phytolith (Fig. 7) and pollen evidence (Fig. 6) from MU26i in Trench 2 shows early colonisers use a mixed grain/leaf fodder diet for ruminant livestock, with a move to grain and grass later on for larger herbivores, which are represented in MU18b; a pattern which is also evident at Karksi. The phytolith 
assemblage from the trampled lenses of herbivore, caprid pellets at the base of the sequence (MU 26i-iii) comprises arboreal (dicotyledon) and grass (monocotyledon) phytoliths, particularly spherical (or globular psilate) forms that occur with broad-leafed foliage and the bark of twigs (Delhon et al. 2008; Piperno 2006). Monocotyledons can produce up to twenty times more phytoliths than dicotyledons (shrubs/trees), and so dicotyledon phytoliths are under-represented in the phytolith record; therefore, a direct comparison between monocotyledons and dicotyledons does not represent the true ratio of grasses to trees/shrubs (Tsartsidou et al. 2007). Consequently, the woody species are very likely to be much more prolific than indicated in the phytolith record, and could indicate the use of leaf fodder in addition to grasses (Delhon et al. 2008) during the earlier occupation at the castle, represented in unit 26. Pollen samples from MU20c, 23b, 26i and 26iii contain significantly higher quantities of Avena-Triticum (67-80\%), with a smaller component of weed, ruderal, grass or another herb pollen. Cellular material from cereal husks is visible on the pollen slides along with clumps of cereal pollen grains.

The range of phytolith morphologies from wetland species, field grasses and weeds, and cereal grasses within stratigraphic units $16 \mathrm{a}$ and $18 \mathrm{~b}$, which contained the dung layers, suggest that horses (or possibly cattle) were both put out to pasture in an area close to water, and also fed on grain, as indicated by the presence of multi-cell dendritic forms from cereal husks (Fig. 4f, 4g). Pollen samples within MU16a1, 16a2, 16a4, 18b and 20b (Fig. 6) show a high degree of uniformity in the pollen sequence with large quantities of Poaceae pollen (up to c. 60\%) and significant quantities of AvenaTriticum (up to $27.6 \%$ ). There are large quantities of pollen of weed taxa strongly associated with arable fields within the dung layers, MU16a4 and 18b, particularly Centaurea cyanus (cornflower) (up to $29.2 \%$ ), along with Agrostemma githago, Scleranthus-type (knawels) and Spergula-type (corn spurrey). Pollen of Ranunculaceae undifferentiated and Anthemis type (chamomiles) also occur in large quantities.

In the samples containing waterlogged plant macroremains, a range of diasporas from different type of plant communities were preserved (Pluskowski et al. 2019a). Although they were not numerous, they still provide evidence for the range of habitats within the immediate vicinity of the castle, which included meadows and pastures, which could be used as a place of pasturage; wild grass seeds were identified in thin section embedded within the in situ dung (MU16a4) (Fig. 4h).

The charred plant macroremains from context 17, the uppermost context, dated to the 2 nd quarter of $14^{\text {th }}$ century, are more interesting. The assemblage in it is interpreted as the remnants of fodder, 
most likely for horses, which was stored in some kind of sack or wooden chest outside the building and subsequently burnt. The sample included a significant quantity of charred oats (Avena sativa) with a small admixture of barley (Hordeum vulgare) and rye (Secale cereale). The grains were not dehusked and appear not to be separated from weeds, which include segetal weeds such as field cockle (Agrostemma githago), false cleavers (Galium spurium) or sheep's sorrel (Rumex acetosella). Currently in Poland oats are still the most popular feed for horses. In medieval Poland oats were viewed as fodder for horses or as a component of a food made for hunting dogs. Historical and archaeobotanical data indicate that oats are present in the human diet, but are not the main element (Dembińska et al. 1999; Karg, 2007; Lityńska-Zając, Wasylikowa, 2005).

\section{Discussion}

The results of these analyses (integrated and summarised in supplementary tables 1 and 3 ) show that at Karksi, livestock were stabled in the area that was to become the High Castle, prior to and during the removal of vegetation probably for its construction as evidenced by a reduction in tree pollen in the pollen record. The clearance of vegetation provided leaf fodder for the animals. Microstratigraphic analysis shows that a spring was dammed to create a small pond to create a watering hole for livestock, and that contained fish possibly used as a food source by occupiers during the construction of the castle. The presence of herbivores is attested by the occurrence of coprophilous fungal spores within the sediment that accumulated at the base of the pond. These microfossils are established indicators of local herbivore activity (van Geel et al. 2003), as the spores are released close to the ground and readily incorporated into the sediments. At Elbląg, the microstratigraphy shows that the area of the outer bailey, the earliest outer ward of the castrum, regularly flooded leaving behind deposits of alluvial sediment that interspersed deposits of occupation materials. The micromorphology results suggest that flooding episodes that are documented in the sediments below the early castra (Nitychoruk et al. 2016) continued during the occupation of the outer bailey.

The coprolite remains from both Karksi and Elbląg show that small ruminants such as sheep and goats were kept in the areas of the early castra under construction and later to form important areas such as the High Castle (Karksi) and the outer ward (Elbląg). In Teutonic Order castles, the High Castle housed the Order's functional and communal rooms, and one or more Outer Baileys (or outer wards), which were usually delineated by defensive walls and moats, contained a number of service buildings and stables, and in the larger castles chapels and administrative spaces (Pluskowski et al 2019b). The evidence at both sites indicates that ruminants were fed both leaf fodder and grain. Micromorphology has been instrumental in identifying trampled sediment and in situ deposits of stabling waste. At 
Karksi, dung fragments from sheep or goat were trampled in the midden. Coprophilous fungal spores at the top of the midden (MU12b) indicate that livestock were roaming in the area. The zooarchaeological evidence from medieval Livonian assemblages (Maltby et al. in press) indicates that the incoming colonists adopted the indigenous livestock husbandry culture, and as a result the absence of any regional diachronic variation is not so surprising. The provisioning of meat to castles and towns was reliant on existing pastoral systems in the countryside, run by indigenous communities, with the only significant change consisting of the reorientation of higher purchasing power communities from strongholds to castles and towns. As attested by documentary sources, raiding was prevalent at this time (Goldschmidt 1979), which may have resulted in the control of resources at the Karksi site by the earliest colonists, with some caprines, as shown by the data presented here, kept in the area that was to become the High Castle. Fish stocks, attested by the presence of fish scales, were potentially retained on site by the creation of a small pond, despite there being a river in the valley bottom.

The occupation material in the earliest outer ward of the castrum at Elbląg is characterised by trampled sediment containing coprolites from small ruminants such as sheep or goats. The next phase of occupation is also characterised by the presence of livestock, but of larger herbivores such as cattle or horses, which is attested by depositions of in situ dung layers (MU16a4 and 18b) containing intestinal parasite eggs and the highest concentrations of coprophilous fungal spores within the profile. This could reflect a general trend evident in the zooarchaeological data from Prussia (Makowiecki et al. in press), which shows a general change over the course of the medieval period in animal husbandry practices with the arrival of the Teutonic Order to larger herbivores such as cattle kept in preference to pigs. However, these in situ dung (stabling) layers (MU16a4 and 18b) could also have been deposited by horses as horseshoes were recovered from mid-13 ${ }^{\text {th }}$ century contexts during the excavation of the outer ward at Elbląg (Fonferek in press), and documentary sources indicate that stud horses were more often stabled in the outer baileys of castles to ensure their safety (Ekdahl 1998). There are similarities between the formation of the in situ stabling layers (MU16a4 and 18b) at Elbląg and a $13^{\text {th }}$ century horse stable within a Moravian medieval bailey, Veselí nad Moravou, Czech Republic (Dejmal et al. 2014), as in both cases the location of the stable is close to water as evident by flooding depositing alluvium.

The uppermost context, 17 in the outer ward at Elbląg, dated to the second quarter of $14^{\text {th }}$ century included a significant quantity of charred oats with a small admixture of barley and rye, and is interpreted as the remnants of fodder, most likely for horses, which adds further support that stud or 
warhorses were stabled in this area. Warhorses were stabled in the outer bailey of Cesis castle, 474 Livonia, during the later phase of the Teutonic Order's rule, c. AD 1480-1503 (Pluskowski et al. submitted). Stable isotope analysis $(\mathrm{O}$ and $\mathrm{H}$ ) of bone collagen and trace element analysis ( $\mathrm{Ba}$ and $\mathrm{Mg}$ ) of bone phosphate show that the horses consumed local water and consumed high $\mathrm{Mg}$, Ba food, possibly grain and fed differently to other horses (Pluskowski et al. submitted). At Veselí nad Moravou, Czech Republic, horses were fed meadow grasses as well as woody vegetation, millet, oat, and less commonly hemp, wheat and rye (Dejmal et al. 2014), which is similar to the mixed grain and pasture evidence, probably hay from MU16a4 and 18b at Elbląg.

The multi-proxy analysis of earliest deposits at Elbląg shows that, in relation to the foddering regimes of smaller ruminants (caprines), they consumed a mixed diet comprising leaf fodder and grain, possibly at a time before more extensive cultivation which could provide sufficient grain for livestock. It is possible that grain fodder is being supplemented with leaf fodder as a result of grain shortage and, perhaps additionally, that this is a seasonal pattern and represents winter livestock alimentation with ruminant enclosed in the outer bailey during the winter months. Isotopic data of sheep/goat remains from the Kulmerland (Prussia) shows that $\delta^{15} \mathrm{~N}$ increased in value from the early to late medieval period due to manuring during agricultural intensification (Müldner et al. in press).

At Karksi, micromorphological analysis of the earliest deposits that begin the infilling of the small pond suggests the use of leaf fodder, with pollen evidence suggesting the dumping of cereal processing waste, including rye, along with the leaf fodder. In later midden deposits, millet was consumed by sheep/goats, which raises the question was millet cultivated or imported (animal) feed? Archaeobotanical studies and research on the history of farming have concluded that until $16^{\text {th }}$ century it was only imported to the Baltic (Dąbrowsk 1962; Latałowa et al. 2007. In Livonia, during the Hanseatic period, millet was the staple of secondary important, as well as lentils or buckwheat. Millet was consumed by the urban middle classes and was presumably imported from the southern Baltics region (Sillaso and Hiie 2007). Pollen evidence from the commandery (the area controlled by the castle) of the Vogt (or Advocate) of Karkus shows oat or wheat from the mid-thirteenth century, rye from the early fourteenth century, and buckwheat during the fifteenth century in the hinterland around Karksi castle (Brown in press). Cereal pollen (from the pond sediment at Karksi, which includes rye, possibly represents small scale production in a largely wooded environment. Charred barley and wheat cereal grains were recovered from the later midden dating to the mid- $13^{\text {th }}$ century. 
508 The results represent an important study of deposits from medieval castles, particularly from the period of active Crusading that are rarely revealed through excavation and in the past have rarely been subjected to an integrated environmental investigation. The integrated results have allowed the potential of these proxies to be powerfully exploited to show new perspectives on the function and development of these castle complexes and their relationships with castle hinterland. In particular,

513 the integration of micromorphology and on-site NPPs has been instrumental in identifying stabling 514 deposits. Where plant macroremains were too fragmentary to survive recovery for analysis, they 515 survived in micromorphology thin-section, such as the remains of millet embedded within the 516 herbivore coprolite at Karksi, and micromorphology provided a micro-contextual approach to understanding the depositional pathways of plant macrofossils and microfossils. The research has produced further information concerning the diachronicity of the range of livestock that the colonising Teutonic Knights kept, whereabouts within the castles they were stabled, and livestock alimentation. While no similar integrated geoarchaeological studies have been undertaken on other Teutonic Order castles in the eastern Baltic, pollen evidence from across Livonia suggests that agricultural intensification was most apparent around the key urban centres and castles where their establishment involved new concentration of people and animals (e.g. Stivrins et al. 2016; Banerjea et al., 2017; Brown et al., 2017). By comparison, rural areas show a measure of continuity in land-use from the preceding late Iron Age, with little evidence for intensification until the $14^{\text {th }}$ century; castles and urban centres therefore play an important role in understanding changing patterns of food procurement and land-use associated with the early years of the Crusades.

\section{References}

530 Akeret, O., Jacomet, S. (1997) Analysis of plant macrofossils in goat/sheep faeces from the Neolithic

531 lake shore settlement of Horgen Scheller - an indication of prehistoric transhumance? Veget Hist $532 \quad$ Archaeobot 6 pp. 235-239

533 Akeret, O., Rentzel, P. (2001) Micromorphology and Plant Macrofossil Analysis of Cattle Dung from 534 the Neolithic Lake Shore Settlement of Arbon Bleiche 3. Geoarchaeology: An International Journal, 16, 535 6, pp. 687-700

536 Akeret, O., Haas, J. N., Leuzinger, U., Jacomet, S. (1999) Plant macrofossils and pollen in goat/sheep 537 faeces from the Neolithic lake-shore settlement Arbon Bleiche 3, Switzerland. The Holocene 9,2 pp. $175-182$ Andersen, S.T., 1978. Identification of wild grasses and cereal pollen. Dan. Geol. Unders. 
540 Arbog. 1978, 69-92.Cushing, E.J., (1967). Evidence for differential pollen preservation in late 541 quaternary sediments in Minnesota. Review of Palaeobotany and Palynology. 4, 87-101.

542 Baker, A.G., Bhagwat S.A., Willis K.J. (2013). Do dung fungal spores make a good proxy for past distribution of large herbivores? Quaternary Science Reviews 62, 21-31.

544 Baker, A.G., Cornelissen, P., Bhagwat, S.A., Vera, F.W.M., Willis, K.J. (2016). Quantification of population sizes of large herbivores and their long-term functional role in ecosystems using dung fungal spores. Methods in Ecology and Evolution. doi:10.1111/2041-210X.12580

547 Banerjea, R.Y. (2019). Settlement life in Prussia at the microscopic scale and the impact on the 548 hinterlands. In A. Pluskowski (ed). The environment, colonisation and the crusader states in medieval 549 Prussia and Livonia: Terra Sacra 1. Turnhout: Brepols. ISBN: 978-2503-55123-6 (In press)

550 Banerjea, R.Y., Badura, M. (2019). Settlement life in Livonia and the impact on the hinterlands: the 551 geoarchaeological and archaeobotanical evidence. In A. Pluskowski (ed) The environment, colonisation 552 and the crusader states in medieval Prussia and Livonia: Terra Sacra 1. Turnhout: Brepols. ISBN: 978553 2503-55123-6 (In press)

554 Banerjea, R.Y., Badura, M., Kalējs, Cerina, A., Gos, K., Hamilton-Dyer, S., Maltby, M., Seetah, K., 555 Pluskowski, A. (2017) A multi-proxy, diachronic and spatial perspective on the urban activities within 556 an indigenous community in medieval Riga, Latvia. Quaternary International 460, 3-21

557 Banerjea, R. Y., Bell, M. G., Matthews, W. and Brown, A. D. (2015) Applications of micromorphology 558 to understanding activity areas and site formation processes in experimental hut floors. 559 Archaeological and Anthropological Sciences, 7 (1). pp. 89-112. ISSN 1866-9565 doi: 560 https://doi.org/10.1007/s12520-013-0160-5

561 Bartlett, R. (1994). The making of Europe: conquest, colonization and cultural change 950-1350. 562 Penguin books, London.

563 Berend, N. (2005). 'Frontiers', in ed. H. J. Nicholson, Palgrave Advances in the Crusades. Basingstoke: 564 Palgrave Macmillan, 148-171.

565 Blomkvist, N. (2009). '12th-14th century European Expansion and its Reception in the Baltic North', 566 in ed. J. Staecker, The Reception of Medieval Europe in the Baltic Sea Region, Visby: Gotland University 567 Press, 431-84.

568 Blaauw, M. and Christen, A. (2011). Flexible palaeoclimate age-depth models using an auto-regressive 569 gamma process. Bayesian Analysis, 6, 457-474.

570 Boyd, C. E. (1995). Bottom Soils, Sediment, and Pond Aquaculture. USA: Chapman \& Hall 571 Brönnimann, D., Ismail-Meyer, K., Rentzel, P., Égüez, N. (2017). Excrements of Herbivores. In C. 572 Nicosia, G. Stoops (eds) Archaeological Soil and Sediment Micromorphology. Chichester, John Wiley \& 573 Sons, pp. 55-66 

environment, colonisation and the crusader states in medieval Prussia and Livonia: Terra Sacra 1. Turnhout: Brepols. ISBN: 978-2503-55123-6 (In press) Brown, A., Badura, M., King., G., Gos, K., Cerina, A., Kalnina, L., Pluskowski, A. (2017) Plant macrofossil, pollen and invertebrate analysis of a mid- $14^{\text {th }}$ century cesspit from medieval Riga, Latvia (the eastern Baltic): Taphonomy and indicators of human diet. Journal of Archaeological Science: Reports 11, 674682

581

Brundage, J. A., (trans. 2003). The Chronicle of Henry of Livonia / Henricus Lettus, New York: Columbia

582 university Press

583 Bullock, P, Fedoroff, N., Jongerius, A., Stoops, G. and Tursina, T. (1985) Handbook for thin section description. Wolverhampton: Waine Reasearch.

585 Charman, D.J., Hendon, D., Woodland, W.A. (2000). The Identification of Testate Amoeboe (Protozoa: Rhizopoda) in Peats. QRA Technical Guide No. 9, Quaternary Research Association: London.

587 Dąbrowski H. 1962. Rozwój gospodarki rolnej w Polsce od 12 do połowy 14 wieku. Studia z Dziejów 588 Gospodarstwa Wiejskiego, 5(1).

589 Dejmal, M., Lisà, L., Fišàkovà, M Nývltovà, Bajer, A., Petr, L., Kočàr, P., Kočàrova, R., Nejman, L., 590 Rybníček, M., Sůvova, Z., Culp, R., Vavrčík, H. (2014) Medieval Horse Stable; The Results of Multi Proxy 591 Inter disciplinary Research. Plos one 9 (3)

592 Delhon, C., Martin, L., Argant, J., Thiébault, S. (2008) Shepherds and plants in the Alps: multi-proxy 593 archaeobotanical analysis of neolithic dung from "La Grande Rivoire" (Isére, France). Journal of Archaeological Science, 35, pp. 2937-2952 Dembińska M., Weaver W. W. (1999). Food and drink in medieval Poland: rediscovering a cuisine of the past. University of Pennsylvania Press, Philadelphia.

597 Ekdahl, S. (1998). 'Horses and crossbows: Two important warfare advantages of the Teutonic Order in 598 Prussia', in H Nicholson (ed.), The Military Orders 2: Welfare and Warfare, Aldershot: Ashgate, 119599 51.

600 Favre, P, Jacomet, S. (1998) Branch wood from the lake shore settlements of Horgen Scheller, 601 Switzerland: Evidence for economic specialization in the late Neolithic period. Veget Hist Archaeobot $602 \quad 7$, pp.167-178

603 FitzPatrick, E.A (1993) Soil microscopy and micromorphology. Chichester : Wiley

604 Finsinger, W., Tinner, W. (2005). Minimum count sums for charcoal concentration estimates in pollen 605 slides: accuracy and potential errors. The Holocene 15 (2), 293- 297. 
606 Fonferek, J. (2019). The environmental setting of the earliest Teutonic Order stronghold in Elbląg, in

607 Ecologies of Crusading, Colonization, and Religious Conversion in the Medieval Baltic, ed. A. G.

608 Pluskowski, Turnhout: Brepols (in press)

609 Grimm, E.C. (2011). Tilia 1.7.16 Software. Springfield, IL: Illinois State Museum, Research and 610 Collection Center.

611 Goldschmidt, W. (1979). 'A general model for pastoral social systems' in Pastoral Production and 612 Society, ed. L'Equipe écologie et anthropologie des sociétés pastorals, Cambridge: Cambridge 613 University Press, 15-27.

614 Ismail-Meyer, K., Rentzel, P., \& Wiemann, P. (2013). Neolithic lake-shore settlements in Switzerland: 615 new insights on site formation processes from micromorphology. Geoarchaeology, 28, 317-339.

616 Ismail-Meyer, K., Stolt, M.H. \& Lindbo, D.L. (2018) Soil organic matter. In: Stoops, G., Marcelino, V., 617 Mees, F. (eds.) Interpretation of micromorphological features of soils and regoliths. Elsevier, 618 Amsterdam, pp 471-512.

619 Jóźwiak, S. and Trupinda, J. (2012). Krzyżackie zamki komturskie w Prusach, Toruń: Wydawnictwo 620 Naukowe Uniwersytetu Mikołaja Kopernika.

621 Kattenberg, A.E., Aalbersberg, G. (2004) Archaeological prospection of the Dutch perimarine 622 landscape by means of magnetic methods. Archaeol. Prospect. 11, pp. 227-235

623 Karg, S. (ed.) (2007). Medieval food traditions in northern Europe. National Museum, Copenhagen, 624 PNM Studies in Archaeology and History 12.

625 Kukk T., Kull K. (1997). Wooded Meadows [Puisniidud]. - Estonia Maritima 2: 1-249. 626 http://www.zbi.ee/ kalevi/wooded.htm

627 Krug, J.C., Benny, G.L., Keller, H.W. (2004). Coprophilous fungi. In: Foster, M., Bill, G. (eds.), Biodiversity 628 of Fungi. Inventory and Monitoring Methods, 467-499. Elsevier Science: Amsterdam.

629 Latałowa M., Badura M., Jarosińska J., Święta-Musznicka J. (2007). Useful plants in medieval and post630 medieval archaeobotanical material from the Hanseatic towns of Northern Poland (Kołobrzeg, Gdańsk 631 and Elbląg). National Museum (PNM), Studies in Archaeology\&History. Vol. 12, Copenhagen, p.: 3963272.

633 Lityńska-Zając M., Wasylikowa K. (2007). Przewodnik do badań archeobotanicznych. Wyd. Sorus, 634 Poznań.

635 Makowiecki, D., Zabilska-Kunek, M., Seetah, K., Jarzebowski, M., Pluskowski, A. (2019) Farming, 636 Hunting and Fishing in Medieval Prussia: The Zooarchaeological Data. In A. Pluskowski (ed). The 637 environment, colonisation and the crusader states in medieval Prussia and Livonia: Terra Sacra 1. 638 Turnhout: Brepols. ISBN: 978-2503-55123-6 (In press) 
640 York: John Wiley and Sons.

641 Mackenzie, W.S. and Guilford, C. (1980) Atlas of Rock Forming Minerals. Harlow: Longman Group Ltd.

642 Maldre L (2003) Karjakasvatus Eestis. Eesti aastal 1200, ed Mägi M (Kirjastus Argo, Tallinn) pp. 163643172.

644 Maltby, M., Pluskowski, A., Rannamäe, E., Seetah, K. Farming, Hunting and Fishing in Medieval Livonia: 645 The Zooarchaeological Data. (2019). In A. Pluskowski (ed). The environment, colonisation and the 646 crusader states in medieval Prussia and Livonia: Terra Sacra 1. Turnhout: Brepols. ISBN: 978-2503647 55123-6 (In press)

648 Matuszkiewicz W. (2008). Przewodnik do oznaczania zbiorowisk roślinnych Polski. Wydawnictwo 649 Naukowe PWN, Warszawa.

650 Mazier, F., Galop, D., Gaillard, M.J., Rendu, C., Cugny, C., Legaz, A., Peyron, O., Buttler, A. (2009). 651 Multidisciplinary approach to reconstructing local pastoral activities: an example from the Pyrenean 652 Mountains (Pays Basque). The Holocene 19(2), 171-188.

653 Mees, F. and Stoops, G., (2018) Sulphidic and Sulphuric Materials. In: Stoops, G., Marcelino, V., Mees, 654 F. (eds.) Interpretation of micromorphological features of soils and regoliths. Elsevier, Amsterdam, pp $655 \quad 347-376$.

656 Mirek Z, Piękoś-Mirkowa H, Zając M (2002) Flowering plants and Pteridophytes of Poland: a checklist. 657 Szafer Institute of Botany, Polish Academy of Science, Kraków.

658 Moore, P.D., Webb, J.A., Collinson, M.E., (1991). Pollen Analysis. Blackwell, Oxford

659 Morandi, L. F. (2018). Non-pollen palynomorphs as an aid to the identification of ancient farming 660 activities: an experimental and archaeological approach. Unpublished PhD dissertation, University of 661 Reading

662 Müldner, M. Scull, C. and Makowiecki, D. (2018). 'Carbon and Nitrogen stable isotope evidence for 663 animal husbandry and environmental change in the medieval Kulmerland', in Ecologies of Crusading, 664 Colonization, and Religious Conversion in the Medieval Baltic, ed. A. G. Pluskowski, Turnhout: Brepols 665 (In press)

666 Murray, A. V. ed. (2001). Crusade and Conversion on the Medieval Baltic Frontier, Aldershot: Ashgate. 667 Nitychoruk, J., Szymanek, M., Bińka, K., Kasprzycka, M. and Zbucki, Ł. (2016). 'Changes of 668 Sedimentation in the Drużno Lake based on Geoarchaeological Data from the Teutonic Fortress in 669 Elbląg, North Poland', Acta Geologica Polonica 66/1, 85 -98.

670 Jenkins, E.L. and Rosen, A.M., (2007). The Phytoliths. In: Finlayson, B. and Mithen, S., eds. The Early 671 Prehistory of Wadi Faynan, Southern Jordan: Archaeological survey of Wadis Faynan, Ghuwayr and al- 

Books, 429-436.

Piperno, D. R. (2006). Phytoliths: A Comprehensive Guide for Archaeologists and Paleoecologists.

676 Pluskowski, A. G. (2012). The Archaeology of the Prussian Crusade: Holy War and Colonisation.

677 Abingdon, Routledge

678 Pluskowski, A. G. (2019). The environment, colonisation and the crusader states in medieval Prussia and Livonia: Terra Sacra 1. Turnhout: Brepols. ISBN: 978-2503-55123-6 (In press) Prussia and Livonia: Terra Sacra 1. Turnhout: Brepols. ISBN: 978-2503-55123-6 (In press) Pluskowski, A.G., Brown, A.D., Banerjea, R., Makowiecki, D., Seetah, K., Rannamäe, E., Jarzebowski, M., Kreen, J., Klavins, K. (2019b). From the convent to the commandery: the pivotal role of the environment in defining the medieval Baltic Ordensland. Submitted to Quellen und Studien zur Geschichte des Deutschen Orden (in press)

687 Pluskowski, A., Seetah, K., Maltby, M, Banerjea, R., Black, S., Kalniṇš, G., (2018). Late Medieval Horse 688 Remains at Cēsis Castle (Latvia) and the Teutonic Order's Equestrian Resources in Livonia. Medieval 689 Archaeology 62:2, 351-379

690 Pümpin, C., Le Bailly, M., Pichler, S. (2017). Ova of Intestinal Parasites. In C. Nicosia, G. Stoops (eds) Archaeological Soil and Sediment Micromorphology. Chichester, John Wiley \& Sons, pp. 91-98 Rannamäe, E. and Lõugas, L. (2019). Animal exploitation in Karksi and Viljandi (Estonia), in the Late Iron Age and Medieval Period, in In A. Pluskowski (ed) The environment, colonisation and the crusader states in medieval Prussia and Livonia: Terra Sacra 2. Turnhout: Brepols (in press) Rasmussen, P. (1993) Analysis of sheep/goat faeces from Egolzwil 3, Switzerland: evidence for branch and twig foddering of livestock in the Neolithic. Journal of Archaeological Science 20, pp. 479-502 Reinhard, K. J., Confalonieri, U. E., Hermann, B., Ferreira, L. F. \& De Aranjo, A. D. G. (1986). Recovery of parasite remains from coprolites and latrines: aspects of paleoparasitological techniques. Homo 37, 217-239.

Scholz, k. and wojtecki, D., (trans. 1984). Chronik des Preussenlandes / Peter von Dusburg, Darmstadt: wissenschaftliche Buch gesellschaft Sillaso, Hiie (2007) - An archaeobotanical approach to investigating food of the Hanseatic period in 703 Estonia. National Museum (PNM), Studies in Archaeology\&History. Vol. 12, Copenhagen, pp. 73-96. Stoops, G. (2003) Guidelines for Analysis and Description of Soil Thin Sections. Madison: Soil Science Society of America. 
Tsartsidou, G., Lev-Yadun, S., Albert, R-M., Miller-Rosen, A., Efstratiou, N \& Weiner, S. (2007) The phytolith archaeological record: strengths and weaknesses evaluated on a quantitative modern reference collection from Greece. Journal of Archaeological Science 34, 1262-1275.

Valk, H., Rannamäe, E., Brown, A.D., Pluskowski, A.G., Badura, M., Lõugas, L. (2012). Thirteenth century cultural deposits at the castle of the Teutonic Order in Karksi. Archaeological Fieldwork in Estonia, 73-92

van Geel, B. (2001). Non-pollen palynomorphs. In: Smol, J.P., Birks, H.J.B., Last, W.M. (eds.), Tracking Environmental Change Using Lake Sediments. Volume 3: Terrestrial, Algal and Siliceous indicators, 99119. New York.

van Geel, B., Buurman, J., Brinkkemper, O., Schelvis, J., Aptroot, A., van Reenen, G.B.A., Hakbijl, T. (2003). Environmental reconstruction of a Roman Period settlement site in Uitgeest (The Netherlands), with special reference to coprophilous fungi. Journal of Archaeological Science 30(7), 873-883.

Villagran, X. S., Huisman, D. J., Mentzer, S. M., Miller, C. E., Jans, M. M. (2017). Bone and other skeletal tissues, In C. Nicosia, G. Stoops (eds) Archaeological Soil and Sediment Micromorphology. Chichester, John Wiley \& Sons, pp. 11-38

Wood, J.R., Wilmshurst, J. M. (2013). Accumulation rates or percentages? How to quantify Sporormiella and other coprophilous fungal spores to detect late Quaternary megafaunal extinction events. Quaternary Science Reviews,77, 1-3.

Yeloff, D., Charman, D., van Geel, B., Mauquoy, D. (2007). Reconstruction of hydrology, vegetation and past climate change in bogs using fungal microfossils. Review of Palaeobotany and Palynology, 146(1), 102-145.

\section{Figure captions}

Figure 1. Map showing the location of Karksi, in present day Estonia, and Elbląg, in present day Poland. Figure 2. a) Plan of Karksi castle with the locations of excavation Trenches 1, 2 and 3-sample in this research come from Trench 1; b) Photograph of the profile from Trench 1; c) Section drawing from Trench 1, showing the location of monolith samples 241 and 242, and the red box highlights the area of interest at the base of the sloping edge; d) scans of micromorphology slides prepared from monolith 241 , and the related microstratigraphic units $(10 a=$ levelling surface, $12 a=$ leaf litter, $12 b=$ trampled discard deposits, $13 a=$ compacted accumulation of leaf fodder, $13 b=$ trampled leaf fodder, 13c=aqueous accumulation, 14a=accumulation, 14b=redeposited sediment).

Figure 3 a) photograph of trench 2, from excavations in 2013 at the Archaeology and History Museum, Elbląg- the red line shows the profile that was selected for sampling in photograph $b ; b$ ) the profile in 
Trench 2, Elbląg that was selected for environmental sampling; c) location of monoliths 1 (blue), 2 (green), 3 (yellow) and 4 (orange), and the white box shows the area in photograph $d$ where samples were collected for analysis of phytoliths and plant macroremains; d) the major stratigraphic units that were identified during excavation and locations of the samples that were collected for analysis of the plant macroremains; e) scans of micromorphology slides prepared from scans of micromorphology slides prepared from monoliths 1-4, and the related microstratigraphic units (16a1=Discard/ abandonment debris, 16a2=Decayed leaf litter, 16a3= Alluvium, 16a4= In situ stabling crust, 18b= In situ oxidised dung, 20b= Constructional/ levelling wood, 20c= Decayed constructional/ levelling wood, $23 a=$ Alluvium, 23b= Reworked occupation surface, $25=$ Alluvium, $26 i=$ Mixed: trampled dung and alluvium, 26ii= Mixed: trampled dung and alluvium, 26iii= Mixed: trampled dung and alluvium).

Figure 4. Micromorphology photomicrographs from Karksi: a) Cross-section of a birch leaf, MU12a, b) Fish scales, MU13a, c) Millet fragments embedded within a caprine coprolite, MU12b; and Elbląg: d) stabling crust, MU16a4, e) Intestinal parasite ova, Ascaris sp., MU16a4, f and g) dendritic multi-cell phytolith formations within dung, MU18b, h) cross-section of a wild grass seed, MU16a4.

Figure 5. Karsksi: summary pollen and NPPs diagram showing the abundance of key pollen types, dung spores and aquatic microfossils (values expressed as microfossil no. $/ \mathrm{cm}^{3}$ ). Dots mark presence where abundance was low.

Figure 6. Elbląg: summary pollen and NPPs diagram showing the abundance of key pollen types dung spores, aquatic microfossils and eggs of intestinal parasites (values expressed as microfossil no./ $\mathrm{cm}^{3}$ ). Dots mark presence where abundance was low.

Figure 7. Elbląg: diagram showing abundance monocotyledon and dicotyledon phytolith forms.

\section{Supplementary tables}

Sup 1. Integrated plant macroremains, palynology and micromorphology datasets from Karksi, Estonia.

\section{Sup. 2. Micromorphology sediment descriptions, Karksi, Estonia}

Sup 3. Integrated plant macroremains, palynology and micromorphology datasets from Elbląg, Poland. Sup. 4. Micromorphology sediment descriptions, Elbląg, Poland. 